Машински факултет

Универзитет у Београду

доц. др Данијела Ђорђевић**

Пољопривредни факулте

Универзитет у Београду

\title{
СТУДЕНТСКА ПЕРЦЕПЦИЈА УСМЕНОГ ИЗЛАГАҢА У НАСТАВИ ЕНГЛЕСКОГ ЈЕЗИКА НА УНИВЕРЗИТЕТСКОМ НИВОУ
}

\section{Сажетак}

Усмено излагање често се помиње у литератури као важан део наставе страног језика на универзитетском нивоу. Циљ овог истраживања јесте да утврди како студенти перципирају искуство излагања на стручну тему на енглеском језику. Узорком су обухваћени студенти прве године Пољопривредног и Машинског факултета Универзитета у Београду који су у оквиру курса Енглеског језика имали задатак усменог излагања на стручну тему. Резултати ове студије се могу даље користити за будућа истраживања о значају усмених излагања у методици наставе енглеског језика на универзитету.

Кључне речи: усмено излагање, енглески језик за посебне намене, студентска анксиозност, универзитетска настава

\section{1. Увод}

Поред четири основне језичке вештине (читање, слушање, писање и говорење) које се усвајају и оцењују током учења страног језика, вештина усменог излагања привлачи све више пажње као тема за истраживање.

\footnotetext{
* Машински факултет, Краљице Марије 16, Београд 11000 tvesic@mas.bg.ac.rs

** Пољопривредни факултет, Немањина 6, Београд 11080 ddj@agrif.bg.ac.rs
} 
Усмена излагања су важна за науку и умрежавање научника, како признатих, тако и оних који тек започињу своје академске каријере, али и за друге делатности у којима се захтева стална усмена комуникација.

Усмено излагање често се помиње у литератури као саставни део наставе страног језика на универзитетском нивоу. Поред развијања основних, горенаведених језичких вештина, рад на вештини усменог излагања је од великог значаја и за адекватно функционисање студената у њиховом будућем професионалном окружењу. Специфичност курсева страног језика на универзитетском нивоу је у томе што се већина студената по први пут сусреће са стручном терминологијом на страном језику. Задатак осмишљавања излагања на стручну тему и суочавање са ситуацијом излагања на страном језику у јавности за велики број студената представља изазов, али и велико оптерећење. Већина студената по први пут излаже на страном језику, а један број студената није имао много прилика ни да излаже на матерњем језику.

Предмет овог рада односи се на примену усмених излагања у настави енглеског језика на нефилолошким факултетима. Циљ истраживања био је да се утврди како студенти перципирају искуство усменог излагања на стручну тему на енглеском језику, да се утврде чиниоци који могу да утичу на успешност излагања, као и да се у овом погледу упореде студенти два различита факултета, Пољопривредног и Машинског факултета Универзитета у Београду. Коришћен је упитник конструисан за потребе истраживања, а подаци су обрађени квантитативно.

Рад је организован на следећи начин. У другом делу најпре ћемо се осврнути на ранија истраживања која су се бавила питањима фактора који утичу на усмено излагање студената на страном језику и анксиозности која при томе настаје. У трећем делу описаћемо методологију по којој је спроведено истраживање, а у четвртом ћемо представити најважније резултате. У закључном делу прокоментарисаћемо налазе истраживања и формулисати препоруке за будућа истраживања на сличне теме.

\section{2. Усмена излагања и језичка анксиозност}

У литератури се наводи да усмена излагања представљају један од најефектнијих начина да се размене информације, те да вештина 
излагања презентације на занимљив начин може умногоме да утиче и на успешност самог излагача (Anholt 2006: xvi). Иако се често може чути како неко има мање или више дара за излагање, истиче се да усмено излагање није само уметност (енгл. art), већ и стечена вештина (енгл. acquired skill), као и да већина студената може побољшати своја усмена излагања уз одговарајуће смернице (Anholt 2006: xvii). Усмена излагања су такође неопходна и у другим областима изван науке - на пример, савремене компаније све више захтевају од запослених да имају добро развијену вештину јавног излагања.

Сходно томе, два најважнија циља усменог излагања јесу да се студенти оспособе за успешан рад у будућем радном окружењу или за могућу академску каријеру (Živković 2014: 468). Као предности увежбавања вештине усменог излагања код студената издвајају се, између осталих, премошћавање јаза између учења и употребе језика, затим коришћење све четири језичке вештине на природно интегрисан начин, помагање студентима да прикупе и организују податке, тимски рад, подстицање аутономије код студената и сл. (King 2002: 402). С друге стране, иако је усмено излагање корисна активност којом се може побољшати познавање страног језика, само излагање за студенте углавном представља веома стресну ситуацију и извор анксиозности (King 2002: 404).

Анксиозност која прати усмена излагања може се посматрати као манифестација посебне врсте анксиозности која настаје услед говорења у јавности (енгл. public speaking anxiety) (Bodie 2010: 71). У ситуацији излагања на страном језику, овај тип анксиозности преплиће се са појавом језичке анксиозности узроковане страним језиком (енгл. foreign language anxiety), која укључује анксиозност при комуникацији на страном језику, испитну анксиозност и страх од негативне евалуације, како наставника, тако и вршњака/колега (Horwitz, Horwitz \& Cope 1986: 127-128)․․ Имајући ово у виду, у литератури се наводи да су главне потешкоће које доводе до неуспешних студентских усмених излагања говорна анксиозност, груп-

1 Постоје многа емпиријска истраживања на тему анксиозности узроковане страним језиком, а велики број ослања се на скалу за мерење језичке анксиозности у случају учења страног језика у разредној ситуацији (енгл. Foreign Language Classroom Anxiety Scale) (Horwitz, Horwitz \& Cope 1986). Оваква истраживања спроведена су и у нашој средини на ученицима основне школе (нпр. Suzić 2016; 2017). 
но досађивање и ограничене вештине излагања (King 2002: 404). Поред тога, разлози услед којих може доћи до нелагодности приликом презентовања jесу брига (Addison et al. 2003) и анксиозност од публике (Ayres 1990). Говорна анксиозност се може лако уочити ако студент почне да замуцкује, да се презнојава и тешко дише, али се ово може донекле превазићи уколико се укаже на то да је страх од усмених излагања нормална појава (King 2002: 404). Групно досађивање се јавља ако тема коју одређени студент презентује није занимљива осталим студентима или ако студент излаже научени текст аутоматски, без гледања у публику, а пажња се губи нарочито ако студент текст није научио, већ га чита (King 2002: 405).

Увођење усмених излагања у оквиру курса Енглеског језика може бити корисно и подстицајно како за наставнике, тако и за студенте (King 2002: 413), али треба имати у виду да је овакав вид активности изузетно комплексан (Dannels 2003: 166). Показало се да ниво познавања енглеског језика има утицаја на то које врсте бриге студенти имају када је у питању усмено излагање (Tsai 2010: 1245). Анксиозност студената приликом усменог излагања може да потиче и од захтевних критеријума за оцену излагања и ограниченог знања струке (Mohd Radzuan \& Kaur 2011: 1436).

На основу свега реченог, закључује се да је веома важно да се студенти добро припреме за усмено излагање. Истраживања показују да се вештине усменог излагања могу ефикасно развијати, пре свега тако што наставник треба да посвети пажњу доброј организацији излагања и повезивању његових делова (Knežević 2014). Увид у начин на који студенти перципирају искуство усменог узлагања на страном језику може да пружи додатне и важне смернице за адекватну припрему за активности овог типа у настави.

\section{3. Методологија истраживања}

\section{1. Узорак}

Узорком су обухваћени студенти прве године Пољопривредног и Машинског факултета Универзитета у Београду који су у оквиру 
курса Енглеског језика имали задатак усменог излагања на стручну тему на енглеском језику. Задатак студената био је да припреме петоминутно излагање на стручну тему из области машинства, односно, пољопривреде. Студенти Машинског факултета излагали су као група која је бројала од три до пет чланова, док су студенти Пољопривредног факултета излагали појединачно.

Укупно је било 176 испитаника, од тога 125 студената Машинског факултета и 51 студент Пољопривредног факултета. Мушки испитаници (67\%) били су заступљенији у узорку од женских (33\%), а просечна старост испитаника је 19,45 година (SD=,82 ). Већина је завршила гимназију (54\%), а остатак средњу стручну школу (46\%). Највећи број испитаника почео је да учи енглески језик у првом разреду основне школе (62,5\%), а једна трећина још у обданишту (29\%). Око две трећине испитаника (61\% њих) навело је да је енглески језик једини страни језик који говоре, док је 39\% испитаника одговорило да се служе и неким другим страним језиком (француски, немачки, руски, италијански).

\section{2. Инструмент}

За потребе истраживања конструисан је упитник којим се испитује утицај различитих фактора приликом усменог излагања на енглеском у оквиру курса страног језика на универзитетском нивоу. Студенти су упитник попунили анонимно и добровољно, и били су обавештени да ће се добијени резултати користити у научне сврхе. Ставке у упитнику обухватиле су основне социодемографске податке, самопроцену испитаника у погледу знања енглеског језика у целини и по појединим језичким вештинама (читање, конверзација, разумевање говора, разумевање текста, писање, превођење), питања везана за искуство усменог излагања на стручну тему на енглеском језику, попут претходног искуства са усменим излагањем на матерњем и енглеском језику, посебних тешкоћа везаних за излагање на енглеском језику (специфична терминологија, излагање као појединац/део групе, присуство публике (колега или наставника), забринутост због лошег изговора, могућих граматичких грешака и сл.), као и одређене ставове о природи учења енглеског језика. 


\section{4. Резултати истраживања}

У делу о резултатима истраживања најпре ћемо се осврнути на то како испитаници оцењују своје генерално познавање енглеског језика и развијеност различитих језичких вештина, а затим ћемо на налазе који указују на мишљење испитаника везано за усмено излагање на енглеском језику на стручну тему.

Као што можемо видети у Графику 1, већина испитаника своје знање енглеског језика оцењује или као добро (28\%) или као врло добро (28\%). Једна петина студената своје знање процењује као одлично (20\%), док нешто мањи број каже да је њихово знање осредње (18\%) или лоше (6\%).

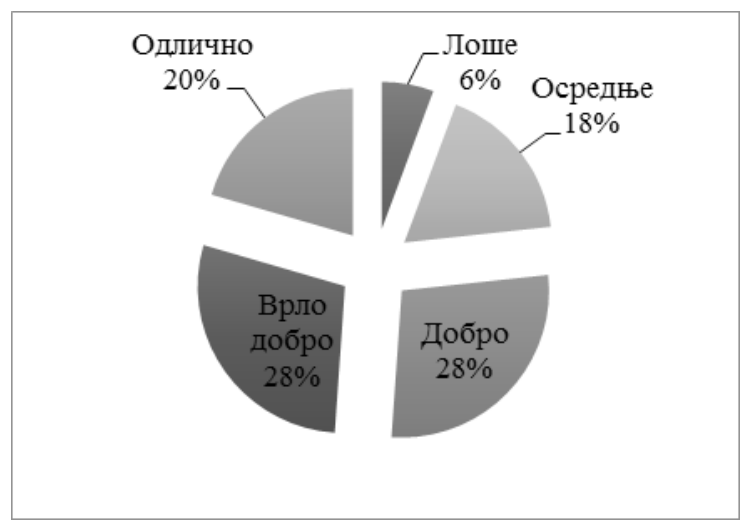

График 1: Самопроцена испитаника о нивоу општег знања енглеског језика

Као најбоље развијене сопствене језичке вештине када се ради о енглеском језику, испитаници наводе разумевање говора (48,9\% испитаника каже да им је ова вештина одлично развијена) и разумевање текста (40,3\% испитаника ову своју вештину оцењује као одлично развијену) (График 2). Такође, према самопроцени испитаника, читање текстова на енглеском језику такође спада у боље развијене вештине (38,1\% студената ову своју вештину оцењују као одлично развијену). Када се ради о вештини конверзације на енглеском језику, која је веома важна за успешност усменог излагања, $26,1 \%$ испитаника процењује да су им вештине конверзације одличне, док подједнак број ову своју вештину оцењује као врло до- 
бру. Према самопроцени испитаника, њихове најлошије развијене језичке вештине у погледу енглеског језику су писање (тек $17 \%$ испитаника процењује ову вештину као одлично развијену код себе) и превод (21,6\% испитаника сматра да им је ова вештина одлично развијена).

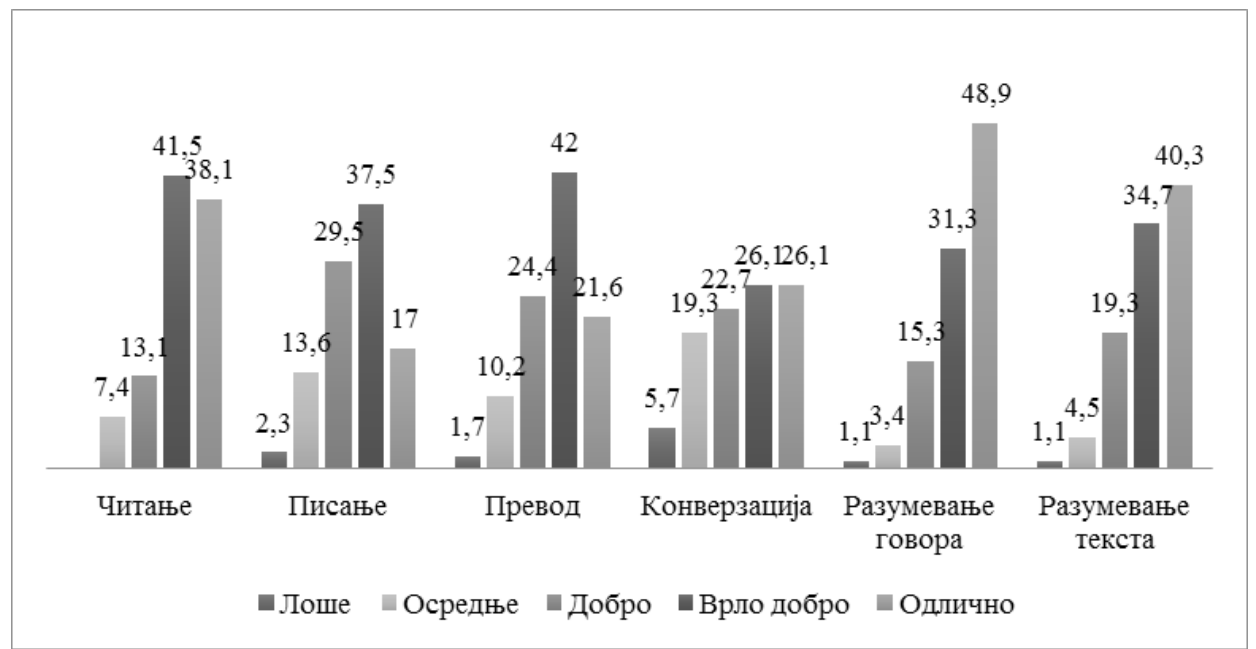

График 2: Самопроцена испитаника о развијености појединих језичких вештина на енглеском језику

Оно што испитанике највише интересује када се ради о учењу енглеског језика на универзитетском нивоу (График 3) јесте читање стручних текстова и усвајање терминологије везане за струку (45,5\%). Дискутовање о одређеним темама на енглеском језику их такође интересује, али више дискутовање о свакодневним, животним темама (25\% студената је рекло да их то највише интересује на курсевима енглеског језика на факултету) него дискутовање о стручним темама (што тврди 21\% испитаника). Оно што студенте најмање интересује на курсу енглеског језика на универзитетском нивоу јесте писање есеја или сажетака (само $1 \%$ испитаника навело је ово као област која их највише интересује) и увежбавање граматике $(7,4 \%)$. 


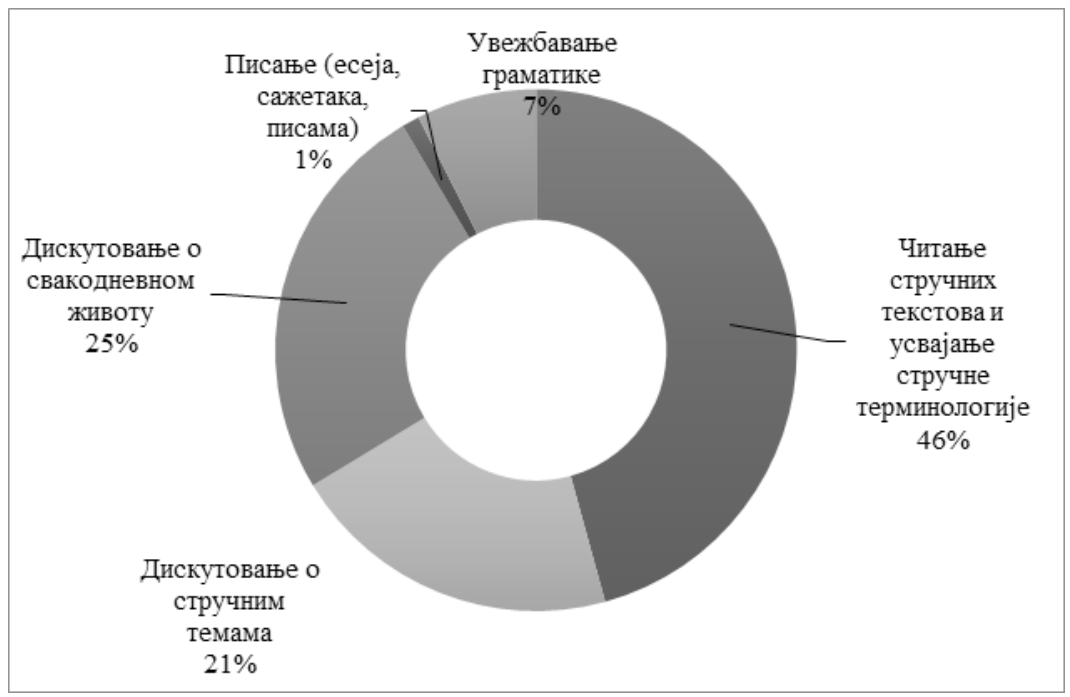

График 3: Области интересовања у учењу енглеског језика на универзитетском нивоу

Раније искуство са усменим излагањем може бити веома важан фактор за успешност овог задатка. Већина испитаних студената навела је да је више пута излагала на матерњем језику као део задатка у оквиру неког предмета (85\%), а само 7\% навело је да никада није имало такав задатак.

Међутим, када се ради о излагању на енглеском језику у оквиру курса енглеског језика, знатно мањи број студената је имао искуства са овим задатком. Чак 38\% студената у овом истраживању никада није излагало на енглеском језику у оквиру курса језика. Отприлике једна трећина испитаника (36\%) је више пута имала излагање на енглеском језику на часу, а 26\% њих је имало овакав задатак само једном.

Када се ради о изворима коришћеним за припрему презентације и усменог излагања (График 4), резултати показују да се студенти углавном ослањају на изворе на енглеском језику који су доступни на интернету, па је тако мало више од половине њих (56\%) навело да су користили сајтове на енглеском језику са стручном тематиком, а једна трећина (31\%) да су користили енциклопедије доступне на интернету, попут Википедије, Британике и сл. Већина испитаних студената каже да је презентацију и усмено излагање припремала свега један дан (49\%), а нешто мањи број неколико дана (40\%). 


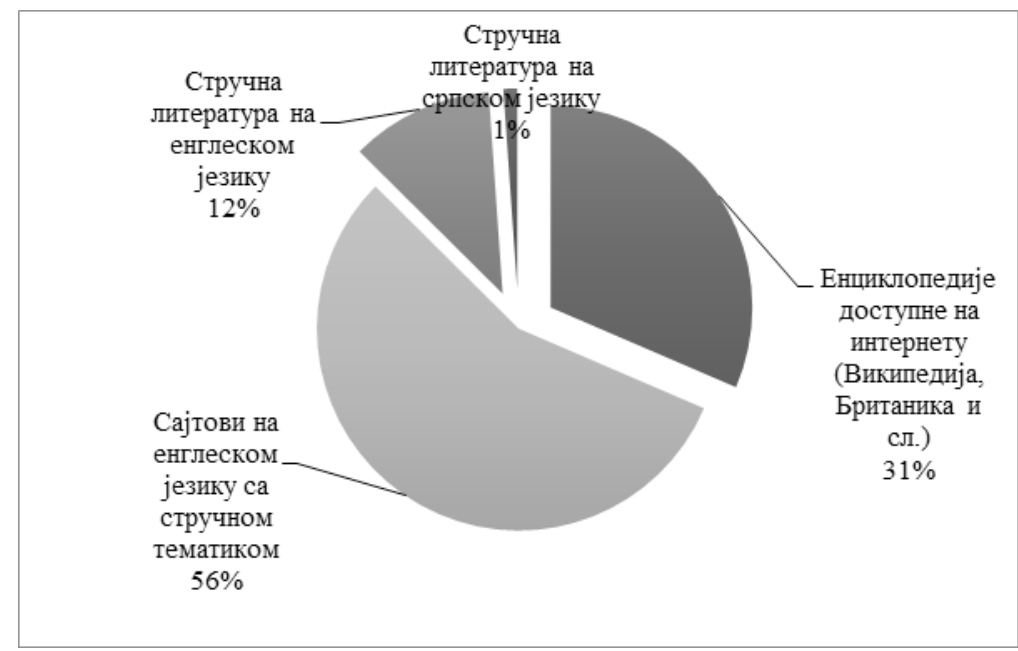

График 4: Извори коришћени за припрему излагања

Интересовало нас је и да ли постоје неке специфичности у прављењу презентације на енглеском језику на стручну тему и могуће потешкоће које се јављају у вези с тим. За већи број испитаника терминологија на енглеском језику неопходна за излагање теме презентације није представљала проблем (42\%), а за приближно исти број студената јесте, али не велики (41\%).

С обзиром на то да су студенти Машинског факултета своју тему излагали у оквиру групе, а студенти Пољопривредног факултета појединачно, постављено им је питање које се односило на то да ли излагање у групи сматрају отежавајућом или олакшавајућом околности. Студенти Машинског факултета који су излагали као група већински (66\%) наводе да им је излагање у групи била олакшавајућа околност. Међутим, на питање да ли би им било лакше да су усмено излагање имали у оквиру групе, студенти Пољопривредног факултета који су излагали појединачно већински су (51\%) одговорили да им је свеједно да ли излажу као појединци или као део групе.

На питање да опишу своја осећања у току усменог излагања на енглеском језику, већина студената (47\%) каже да су били мало нервозни, али и да то није утицало на њихово излагање, док око једне петине испитаника (21\%) каже да су били опуштени (График 5). Међутим, знатан број испитаника (32\%) такође је рекао да су били веома нервозни и да је то утицало на њихово излагање. 


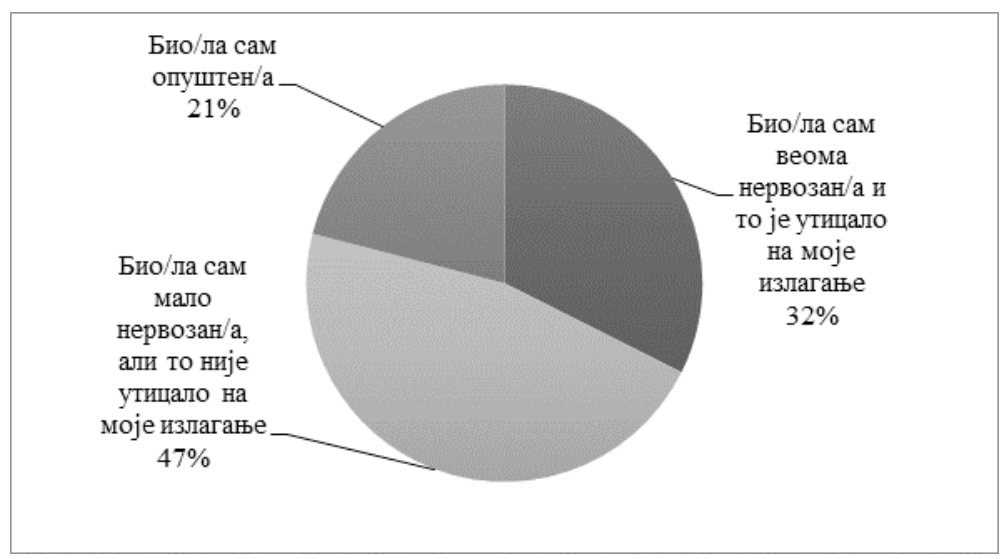

График 5: Осећања испитаника током усменог излагања

У току конструисања упитника, издвојено је неколико чинилаца који би могли да утичу на осећања студената током усменог излагања и испитаницима је постављено питање у ком степену сматрају да је сваки од тих чинилаца имао утицаја на то како су се осећали током презентације: присуство наставника, присуство осталих колега као публике, брига о бодовима, генерално лоше знање енглеског језика, забринутост због лошег изговора и забринутост због могућих граматичких грешака. У случају студената Машинског факултета који су излагали као група, додат је и чинилац бриге о генералном постигнућу групе.

Резултати показују да је присуство наставника донекле утицало на то како су се испитаници осећали током усменог излагања презентације (График 6). Иако је укупно 59,7\% испитаника рекло да је овај фактор мало или нимало утицао на њихово излагање, око 40\% испитаника проценило је да је донекле или у великој мери постојао утицај овог фактора. С друге стране, присуство осталих колега као публике опажа се као чинилац који је код већег броја испитаника имао значајнији утицај на то како су се осећали током излагања него што је то случај са присуством наставника. Наиме, укупно 55,6\% испитаника рекло је да је овај фактор донекле или у већој мери утицао на њихова осећања током усменог излагања. 


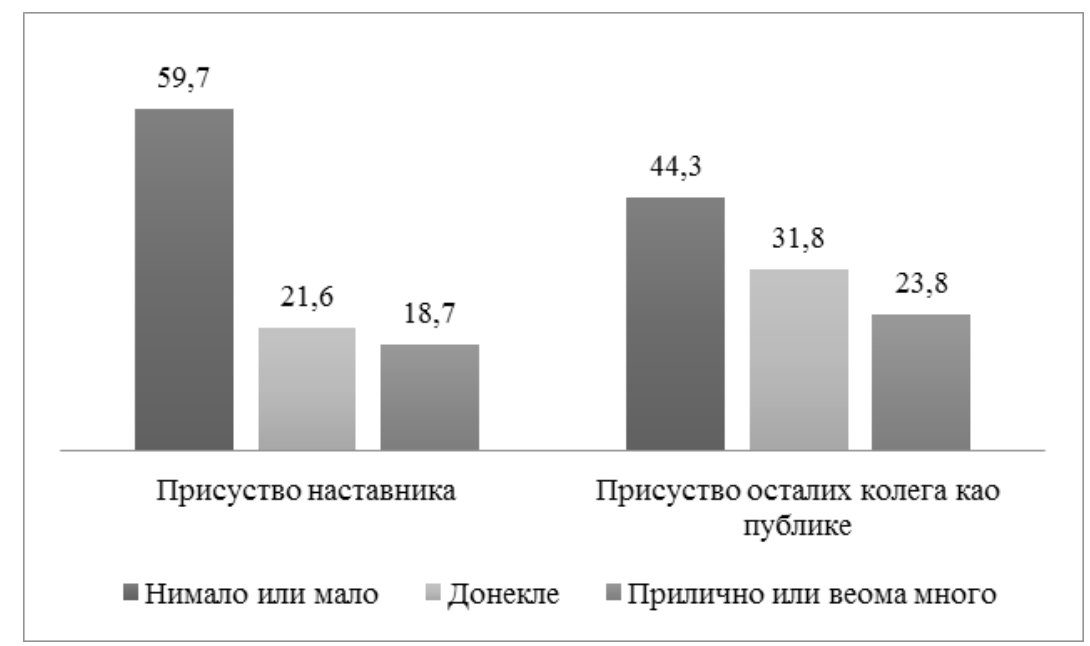

График 6: Степен утицаја присуства наставника и присуства осталих колега као публике на осећања испитаника током излагања (у \%)

Брига о бодовима које задатак усменог излагања вреди за $42,7 \%$ испитаника донекле или у великој мери утицала је на то како су се осећали током излагања (График 7). Генерално лоше знање енглеског језика није оцењено као чинилац који има велики утицај $(76,1 \%$ испитаника каже да је оно мало или нимало утицало на то како су се осећали током усменог излагања).

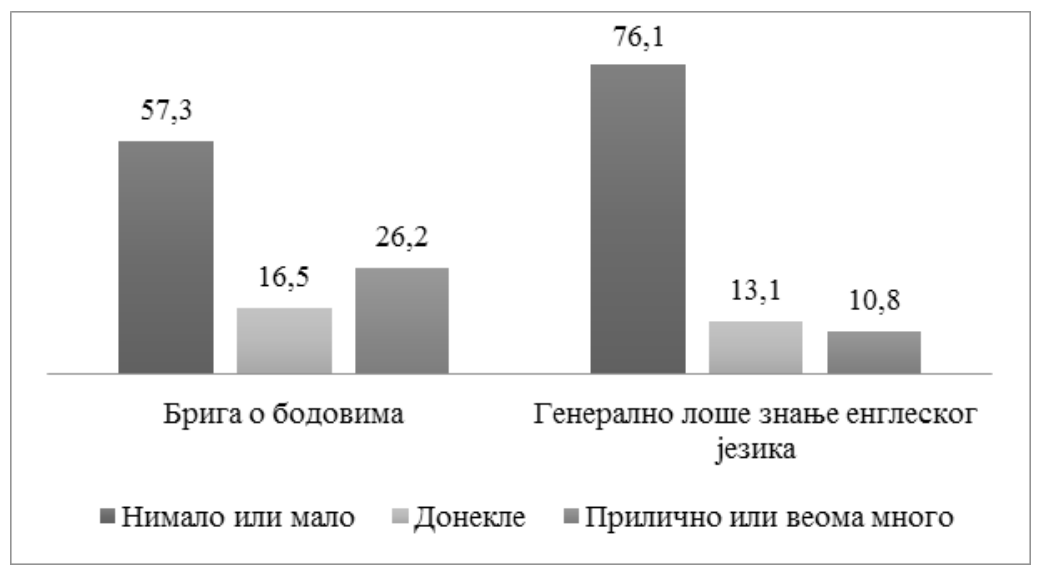

График 7: Степен утицаја бриге о бодовима и генерално лошег знања енглеског језика на осећања испитаника током излагања (у \%) 
Код забринутости због лошег изговора, постоји такође велики број испитаника који кажу да је овај чинилац мало или нимало утицао на њихова осећања (68,8\%), с тим што постоји већи број испитаника $(31,2 \%)$ који процењује да је овај чинилац донекле или у већој мери утицао на то како су се осећали током презентације (График 8). Код забринутости због могућих граматичких грешака, за нешто више од једне трећине испитаника (35,8\%), овај чинилац играо је улогу у томе како су се осећали током презентације на енглеском језику.

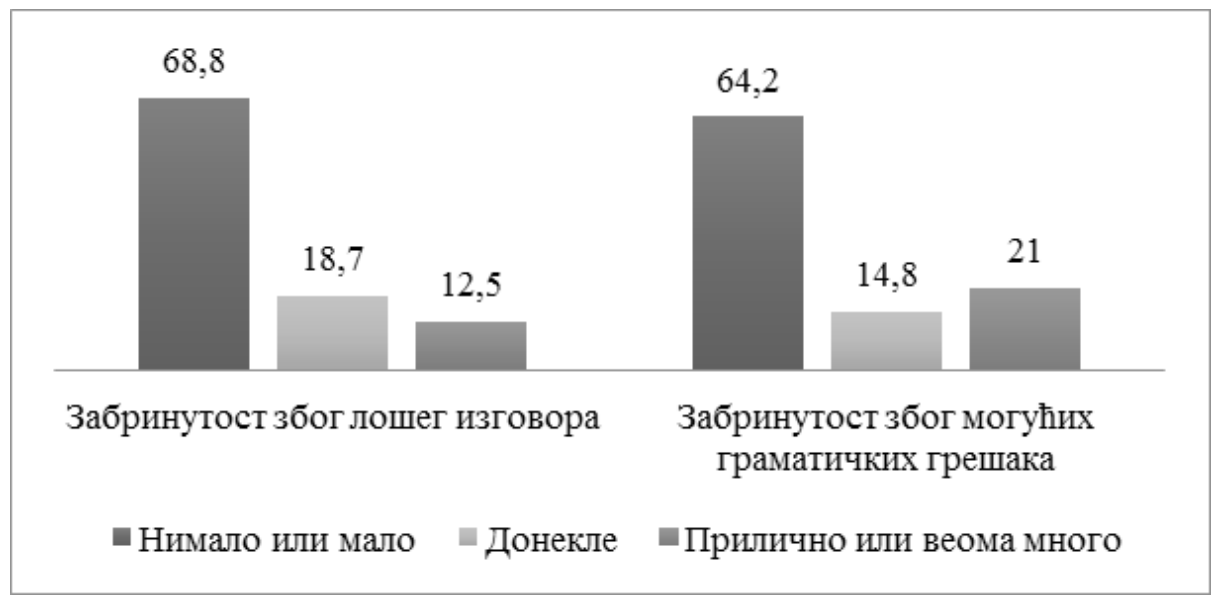

График 8: Степен утицаја забринутости због лошег изговора и забринутости због могућих граматичких грешака на осећања испитаника током излагања (у \%)

Додатни фактор који је процењиван у случају студената Машинског факултета који су излагали као група јесте брига о генералном постигнућу групе. Чак 62,4\% испитаника рекло је да је овај фактор донекле, прилично или веома много утицао на то како су се осећали током свог усменог излагања (График 9). 


\section{Култура универзитета и филологија}

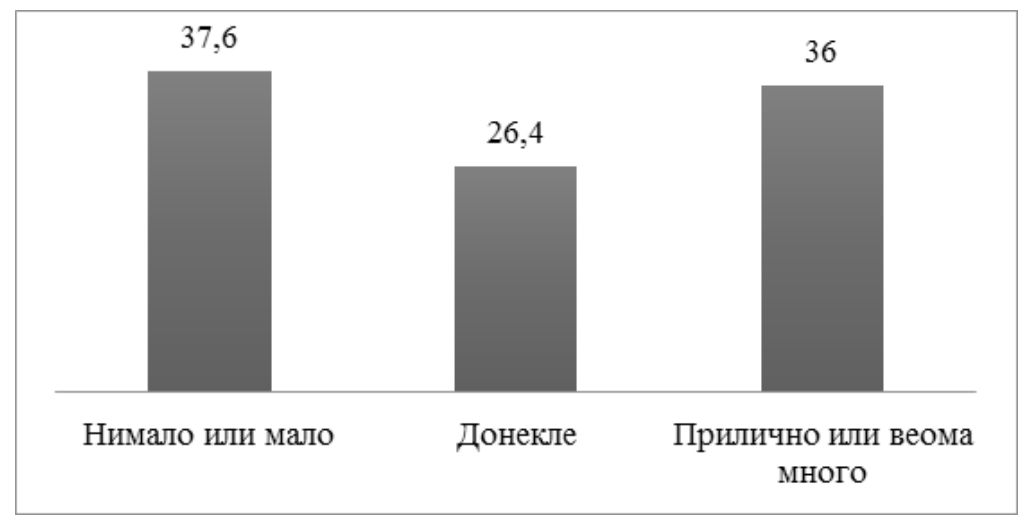

График 9: Степен утицаја забринутости због генералног постигнућа групе на осећања испитаника са Машинског факултета током излагања (у \%)

У погледу опажене корисности задатка усменог излагања на страном језику за одређене ситуације (График 10), као што се могло и очекивати, оцењује се да би ова активност могла бити веома корисна за потребе прављења презентације за друге предмете (83\%), али и за разговор за стипендију или посао на енглеском језику (81\%), као и активности на будућем радном месту (82\%). Учешће на студентским такмичењима у знању је једина понуђена ситуација за коју испитаници не сматрају у овако великом броју да ће им усмено излагање на страном језику бити корисно, мада процењују да им ипак може бити корисна (66\% њих одговорило је потврдно).

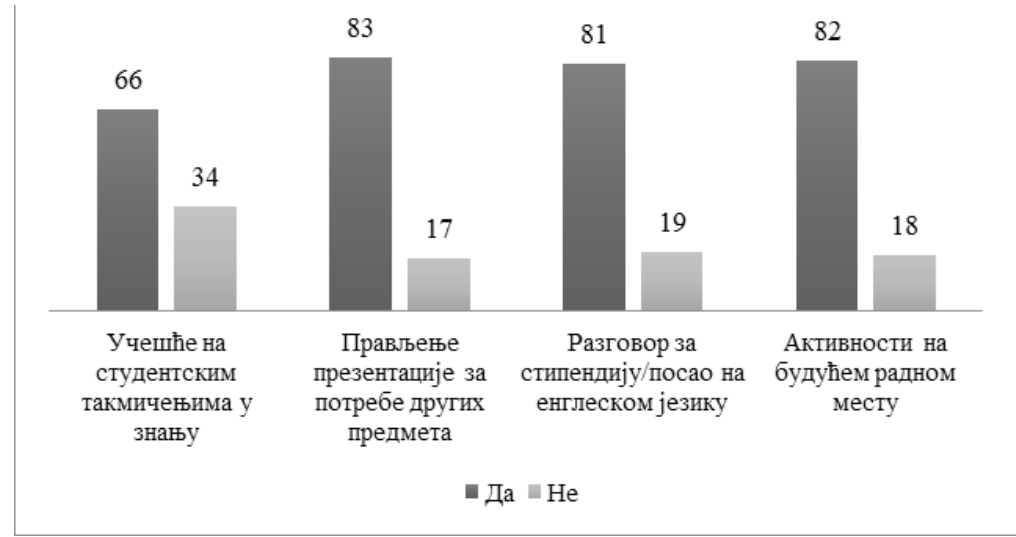

График 10: Процењена корисност задатка усменог излагања на енглеском језику у одређеним академским и професионалним ситуацијама (у \%) 
Резултати додатно показују да постоји значајна повезаност између самопроцене сопствене вештине конверзације на енглеском језику и тога како су се испитаници осећали током усменог излагања. У групи студената који су били веома нервозни током излагања, чак $43,8 \%$ своје вештине конверзације оценило је као лоше или осредње. С друге стране, у групи оних који су се осећали опуштено током усменог излагања на енглеском језику, 59,5\% је оних који су своје вештине конверзације проценили као одличне.

Такође, јавља се значајна повезаност између степена слагања са ставком „Имам проблем када треба да говорим на енглеском језику пред другим људима“ и тога како су се испитаници осећали током усменог излагања (График 11). Већина испитаника, односно, 89,2\% оних који су се осећали опуштено током усменог излагања на енглеском језику нема проблем када треба да говори на енглеском језику пред другим људима, док се 50,9\% оних који су били веома нервозни током излагања делимично или потпуно слаже са тврдњом да имају овакав проблем.

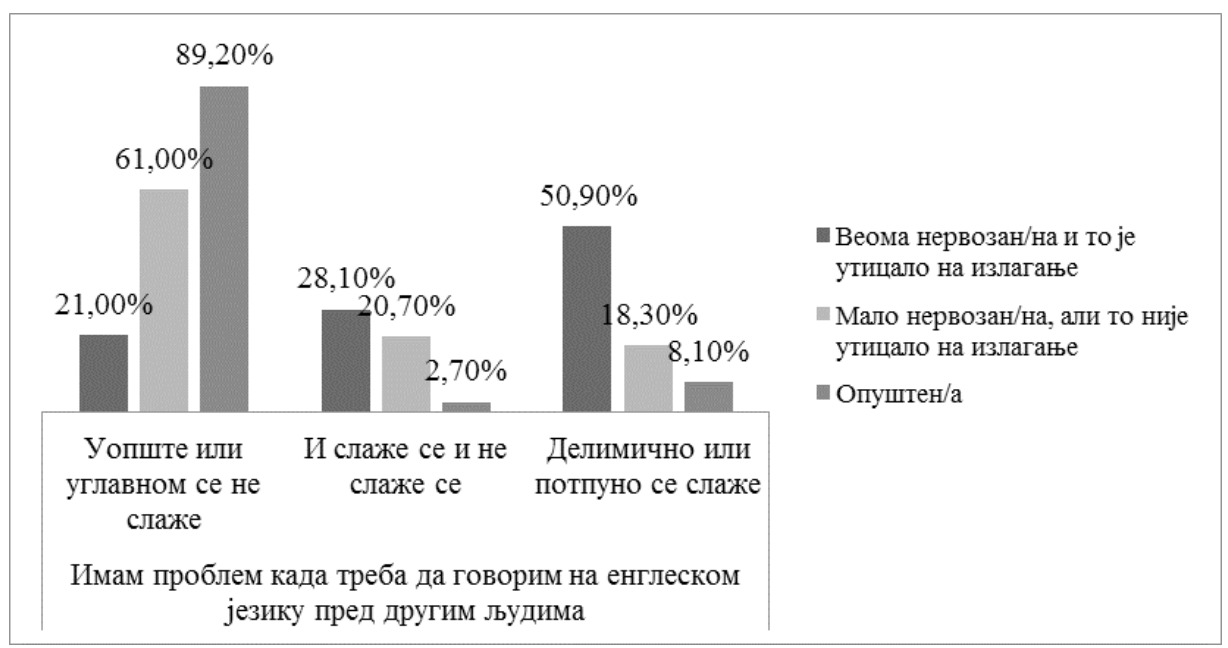

График 11: Веза између осећања лагодности током усменог излагања и опуштености приликом излагања на енглеском језику пред другим људима

Овакав налаз нам додатно указује на то да они студенти који имају страх од говорења у јавности самим тим имају и већи степен бриге у ситуацији усменог излагања на страном језику. 


\section{5. Дискусија и закључна разматрања}

Резултати нашег истраживања спроведеног на студентима прве године Машинског и Пољопривредног факултета Универзитета у Београду показују да студенти нису имали много прилика да усмено излажу на енглеском језику на претходним нивоима школовања. С друге стране, то не утиче на дужину спремања излагања, која је веома кратка (један дан или неколико дана). Извори који се највише користе при припреми излагања на стручну тему на енглеском језику јесу сајтови и специјализоване енциклопедије на енглеском језику доступне на интернету. При припремању презентације, стручна енглеска терминологија представља проблем за један део студената. У погледу чинилаца који су утицали на то како се студенти осећају током излагања, на основу ових података, можемо закључити да је фактор који има највећи утицај присуство колега, а затим брига о бодовима и присуство наставника. Сами испитаници факторе који се односе на знање енглеског језика нису оценили као веома значајне. Забринутост због лошег знања енглеског језика процењена је као нешто што је најмање утицало на осећања студената током излагања, што се може објаснити чињеницом да је веома велики број испитаника своје знање оценио у распону од доброг ка одличном. Међутим, показало се да они студенти који своје вештине конверзације процењују као лошије ипак показују већи степен бриге при усменом излагању.

Студенти два факултета подељени су у мишљењу да ли је лакше усмено излагати у оквиру групе или појединачно. Студенти Машинског факултета, који су имали излагање у групи, у већини сматрају да је то олакшавајућа околност, док студенти Пољопривредног факултета већински кажу да им је свеједно да ли излажу у групи или индивидуално. Међутим, иако је само излагање у групи процењено као олакшавајућа околност, код студената Машинског факултета је брига о генералном постигнућу групе представљала чинилац са важним утицајем на то како су се осећали током усменог излагања на енглеском језику, тј. нешто што је изазивало бригу.

Опште препоруке у вези са превазилажењем анксиозности при усменом излагању које се наводе у литератури јесу постепено излагање ситуацијама у којима треба говорити у јавности, развијање 
позитивне представе о усменом излагању као таквом, као и позитивне свести о себи као говорнику, увежбавање вештина усмерених ка побољшању одређених понашања при усменом излагању и сл. (Bodie 2010: 87-89). С обзиром на то да се у нашем истраживању показало да постоји веза између осећања приликом усменог излагања и самопроцене вештине конверзације на енглеском језику, потребно је радити на оснаживању ове вештине кроз тражење прилике да студенти усмено излажу што више, и то осмишљавањем различитих активности на часу које укључују овакав задатак. Такође, веома важан фактор који утиче на осећања приликом усменог излагања јесте присуство и реакција колега, што се може сматрати манифестацијом анксиозности од публике (Ayres 1990), па би у настави страног језика на универзитетском нивоу требало подстицати укључивање студената у различите краће дискусије у оквиру наставе, током којих би они могли да смање страх од излагања пред колегама. Из свега реченог, закључује се да на вештини усменог излагања треба радити стрпљиво и пажљиво, јер успех излагања зависи од многих фактора, од којих су неку емпиријски потврђени и на узорку студената у овом истраживању.

Најзад, на крају треба указати и на ограничења ове студије истраживање је спроведено на студентима прве године, на самом почетку студија, када је познавање струке и на матерњем језику на нижем нивоу, што може додатно да појача анксиозност при излагању на стручну тему на енглеском језику. Будућа истраживања могла би да обухвате већи број студената различитих нефилолошких факултета и да се усмере на студенте на вишим нивоима студија. Међутим, без обзира на наведена ограничења, резултати овог истраживања могу бити полазна основа за будућа истраживања о значају усмених излагања у методици наставе енглеског језика на универзитету.

\section{Извори и литература:}

Addison, Penny, Ele Clay, Shuang Xie, Chris Sawyer, and Ralph Behnke. "Worry as a function of public speaking state anxiety type". Communication Reports 16 (2003): 125-131. Print. 


\section{Култура универзитета и филологија}

Anholt, Robert. Dazzle 'em with style: the art of oral scientific presentation. San Diego: Elsevier Academic Press, 2006. Print.

Ayres, Joe. "Situational factors and audience anxiety". Communication Education 39 (1990): 283-291. Print.

Bodie, Graham. "A racing heart, rattling knees, and ruminative thoughts: Defining, explaining, and treating public speaking anxiety". Communication Education 59 (2010): 70-105. Print.

Dannels, Deanna. "Teaching and Learning Design Presentations in Engineering: Contradictions between Academic and Workplace Activity Systems". Journal of Business and Technical Communication 17.2 (2003): 139-169. Print.

Horwitz, Elaine, Michael Horwitz, and Joann Cope. "Foreign language classroom anxiety". The Modern Language Journal 70.2 (1986): 125-132. Print.

King, Jane. "Preparing EFL Learners for Oral Presentations". Dong Hwa Journal of Humanistic Studies 4 (2002): 401-418. Print.

Knežević, Ljiljana. „Razvijanje veštine usmenog izlaganja u nastavi stranog jezika na fakultetu“. Nastava i vaspitanje 63.1 (2014): 107-119. Štampano.

Mohd Radzuan, Noor and Sarjit Kaur. "Technical oral presentations in English: Qualitative analysis of Malaysian engineering undergraduates' sources of anxiety". Procedia Social and Behavioral Sciences 29 (2011): 1436-1445. Print.

Suzić, Radmila. „Jezička anksioznost i anksioznost pri komunikaciji na stranom jeziku u razrednoj situaciji“. Metodički vidici 7 (2016): 347-363. Štampano.

Suzić, Radmila. „Kvalitativno istraživanje u oblasti primenjene lingvistike: važnost i značaj intervjua u istraživanju jezičke anskioznosti". Metodički vidici 8 (2018): 329-353. Štampano.

Tsai, Shu-Chiao. "Developing and integrating courseware for oral presentations into ESP learning contexts". Computers and Education 55.3 (2010): 1245-1258. Print.

Živković, Slađana. "The Importance of Oral Presentations for University Students". Mediterranean Journal of Social Sciences 5.19 (2014): 468-475. Print. 


\author{
Tijana Vesić Pavlović \\ University of Belgrade \\ Faculty of Mechanical Engineering
}

Danijela Đorđević

University of Belgrade

Faculty of Agriculture

\title{
STUDENTS' PERCEPTION OF ORAL PRESENTATIONS IN ENGLISH LANGUAGE CLASSES AT THE UNIVERSITY
}

\section{Summary}

Oral presentations are frequently mentioned in the literature as an integral part of teaching the foreign language at the university level. The task of preparing an oral presentation of a discipline-related topic and facing the situation of a public presentation in the foreign language poses a big challenge to a large number of students, as well as a considerable burden. This research is aimed at exploring the students' perception of the experience of oral presentation of a discipline-related topic in the English language. The sample included the first-year students of the Faculty of Agriculture and the Faculty of Mechanical Engineering of the University of Belgrade, who had the task to prepare an oral presentation of a discipline-related topic as a part of their English language classes at the university. Students filled in the questionnaire constructed for the purposes of the study which investigated the influence of different factors during the oral presentation in English. Research results may serve as the basis for further studies of the relevance of oral presentations in the methodology of teaching English at the university, as well as the investigations of students' anxiety and different strategies applied in learning English for professional purposes. 